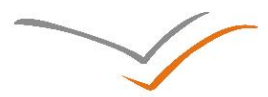

\title{
VERSITA \\ Potential Hidden Losses for Slovakia as a Member of the European Monetary Union
}

\author{
Jozef Stískala \\ Metropolitan University in Prague, Prague
}

Potential Hidden Losses for Slovakia as a Member of the European Monetary Union. Aim of this paper is to evaluate solutions for European crisis in context of Slovak participation in rescue mechanisms. The most evident element is the European stability mechanism. There is no problem with estimation of the potential losses caused by the eurozone break-up for the Slovak Republic regarding ESM. But there are other mechanisms used mainly by the ECB as monetary instruments for stabilization of the financial markets. ECB via these instruments bears potential risk of losses regarding default of the member state(s) that could damage its balance sheet. The Protocol on the statute of the European system of central banks and ECB says that losses from the common mechanisms should be borne by eurozone member states according to their share in the ECB's capital. It is inevitable for the Slovak Republic to realize the size of its exposure via European programmes on the peripheral economies to maintain appropriate attitude as far as the eurozone issues are concerned. The author therefore tries to reveal potential hidden losses for Slovakia as a member of the European monetary union that are not explicitly seen.

Key words: Eurozone, sovereign crisis, bank crisis, TARGET 2, EFSF/ESM, ELA

Potenciálne skryté straty pre Slovensko ako člena Európskej menovej únie. Ciel'om tejto štúdie je zhodnotit' riešenia európskej krízy $v$ kontexte účasti Slovenska na záchranných mechanizmoch. Najevidentnejšou zložkou v tejto oblasti je Európsky stabilizačný mechanizmus. Pokial' ide o ESM, nie je problém odhadnút' potenciálnu výšku straty pre Slovensko, pokial' by došlo k rozpadu eurozóny. Sú tu však ešte iné mechanizmy, ktoré sú využívané ako nástroje menovej politiky ECB na stabilizáciu finančných trhov. ECB cez tieto mechanizmy nesie riziko potenciálnych strát $v$ prípade bankrotu členského štátu/štátov, ktorý by poškodil bilanciu ECB. Protokol o štatúte Európskeho systému centrálnych a ECB uvádza, že straty zo spoločných mechanizmov by mali niest' členské štáty úmerne $\mathrm{k}$ ich podielu na základnom imaní ECB. Je potrebné aby Slovensko si bolo vedomé vel'kosti svojej expozície $v$ európskych programoch realizovaných $v$ periférnych ekonomikách, aby zastávalo správny názor pokial' ide o záležitosti eurozóny. Autor sa preto pokúša odhalit' potenciálne skryté straty pre Slovensko ako člena Európskej menovej únie, ktoré nie sú explicitne viditel'né.

Kl'účové slová: Eurozóna, kríza štátov, banková kríza, TARGET 2, EFSF/ESM, ELA

\section{Introduction}

The Slovak Republic joined the European monetary union on the $1^{\text {st }}$ of January 2009. Slovak crown has been replaced by the single European currency, Euro, and Slovakia transferred part of its competencies to the European Union. One 
of the most important areas is monetary policy, which is currently being executed by the European Central Bank (ECB) in Frankfurt. Participation in the project of a common currency, however, brought risks of losses in case of eurozone member state(s) default. These losses need not only occur under the loans from the EFSF / ESM, but they can also occur as losses on monetary policy conducted by the ECB.

The aim of this study is to point out some specifics of the Slovak position in the mechanisms that have been used to tackle the eurozone crisis. Clarifying operations of monetary policy instruments, we have to conclude that the potential loss from various scenarios of economic development in the eurozone might in Slovakia reach a much larger size than those arising from the EFSF / ESM losses and followed the economic downturn. The author does not attempt to quantify these losses, because such a projection of the future would be a pure speculation. The author's aim is to highlight the extent of potential losses beyond that appointed by the Financial Policy Institute of the Ministry of Finance of the Slovak Republic in connection with a Greek exit from the eurozone. The author in his study attempts to verify the hypothesis that Slovakia could lose more money indirectly through loss of the ECB after an exit of one or more member states from the euro area providing further existence of the European monetary union.

The discussion on this topic began with the publication of the study "Target Loans, Current Account Balances and Capital Flows: The ECB's Rescue Facility" by Hans Werner Sinn and Timo Wollmershäuser, where the aforementioned authors point out the risks of the current balances of TARGET 2. Many other experts as Paul de Grauwe, Karl Whelan, Felix Salmon, William Buiter, Stefano Micossi, Ulrich Bindseil accepted Sinn-Wollmershäuser's view partially or they totally disagreed. This debate led to the author's interest in this subject and the same arguments as those used in case of Germany are applied on the Slovak case. All the profits and losses from joint systems and programmes are in fact shared by proportion to their (country's) capital share in the ECB. What happens in the eurozone as a whole is important because Slovakia will also participate in the total loss. Methodologically, the author decided to proceed by a description of monetary policy that should clarify the practical functioning of the European rescue mechanisms. These mechanisms are further analyzed in order to verify the hypothesis.

\section{One of the most significant summits in the history of the European Union}

One of the most significant summits of the European Council in European history took place on 28 - 29 June, 2012. The conclusions of this meeting indicate that the European Union has decided to move towards a future 
federalization. The first step towards this goal is the creation of a banking union that should lead to the establishment of a fiscal and political union. The eurozone leaders have agreed with the creation of a single mechanism of supervision in accordance with the Article 127 (6) TFEU. It was also decided that the European Stability Mechanism (ESM) would be able to directly recapitalize banks. In this context, we set eyes on Europe, especially on Spain and its problem with the excessively indebted banks and the real estate bubble (Euro area summit statement, 29 June, 2012). But what resounds the most recently is the judgement of the German Constitutional Court (Bundesverfassungsgericht) which states that the ESM is not in conflict with the Basic Law (Grundgesetz) of Germany.

Especially investors are disappointed because the court in Karlsruhe set certain conditions to consider the ESM being a legitimate mechanism to deal with the current debt crisis. The judgement has established that the exposure to the ESM for Germany beyond 190 billion euros will not raise unless the agreement to increase it by both chambers of parliament and approval of German representatives in the Council of the ESM has been reached. It is also assumed that the Bundestag is sufficiently and relevantly informed and will be able to decide whether the increase of funding is necessary (Hipp, 2012).

We will see in practice what other problem could befall us during the implementation of these conditions,. The German contingent approval results apparently from the survey, where $54 \%$ of Germans expressed their opinion that they would like to block the ESM by the Constitutional Court (Connolly, 2012). Of course, the ESM is not the only necessary step to resolve the current European crisis. As Herman Van Rompuy stated in his speech, we have to focus on growth and employment but also to strengthen the democratic legitimacy of the entire European Union. A similar view is expressed in the Conclusions of the European Council (Van Rompuy, 2012; European Council 28/29 June 2012 Conclusions). The negative attitude of citizens towards the European institutions, the complexity of the decision-making process and the prevailing intergovernmental character of the EU do not help people to identify themselves with the citizenship of the European Union. We therefore consider a reform of the whole structure of the EU being essential to avoid future reoccurring of the situation we are facing today. In his speech, Herman Van

Rompuy has outlined the vision for a institutional reform of the Economic and Monetary Union.

\section{The day Europe starts to disintegrate}

Perhaps it is not necessary to present the circumstances in which the crisis in Europe broke out. Just because of the crisis as many people as the population of Slovakia lost their jobs in the period from March 2008 to May 2009. The 
fact that Germany had to bail out IKB Industriebank already in 2007 is also not new. Similar problems have been noticed in other countries, for example with Northern Rock in the UK, or the rescue of the RBS, Lloyds TSB and HBOS, from Benelux Dexia Bank or problem of the Fortis group when Fortis took over the Dutch bank with RBS and ABN Amro Bank. Even Banco Santander as the largest Spanish bank by its asset size did not avoid large financial losses. And so we could continue overseas in the USA where the crisis demonstrated its strength after the bankruptcy of the Lehman Brothers (Hodson, 2009, pp. 939-941).

The fall of the Lehman Brothers is mentioned intentionally. This moment in history is the one when markets no longer believe in a united Europe, a common currency without a harmonized fiscal policy. The following chart describes the development of the interest rate on 10-year bonds of selected EU member states.

\section{Interest rate on 10-year bonds of selected EU member states}

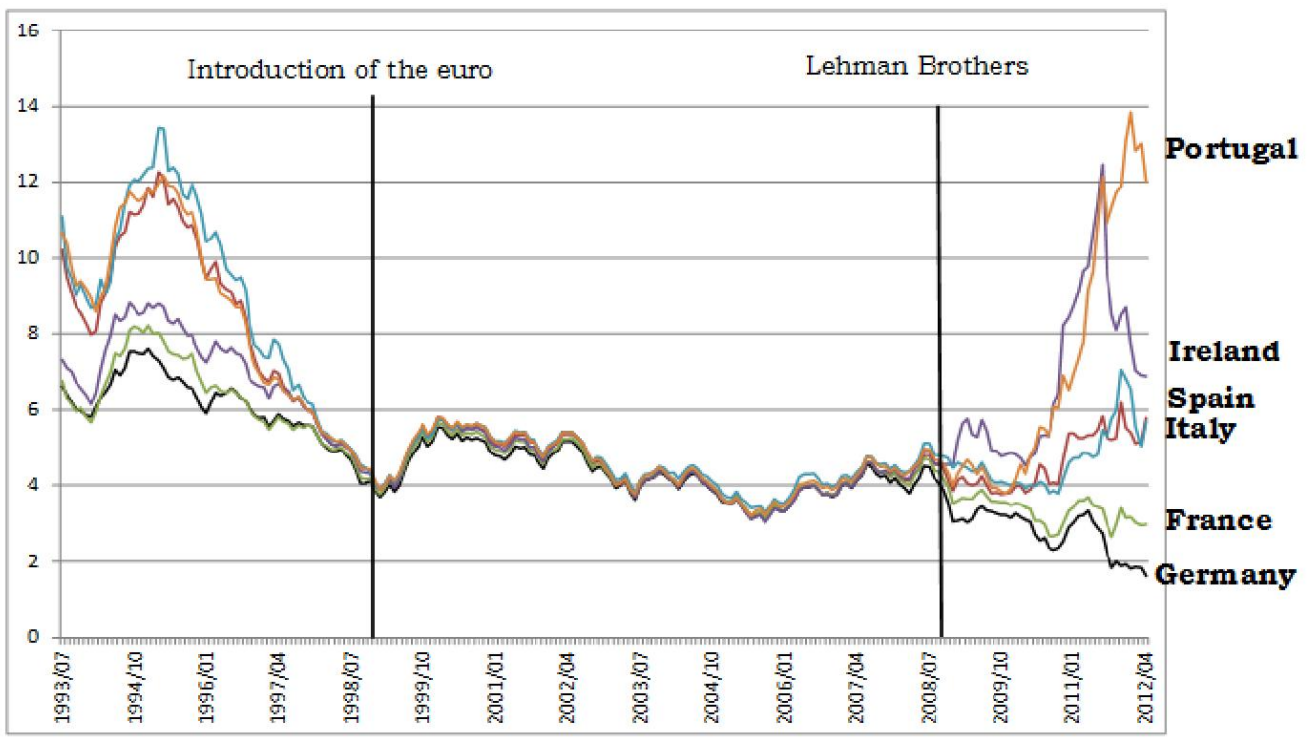

Source: Micossi 2012

The core euro area member states experienced a decrease in the interest rate of their bonds, while the economies at the European periphery face exactly the opposite scenario. The spread of the peripheral economies bonds is larger relative to the German Bund than it was before the introduction of the common currency, as we can see it on the left side of the chart, before the introduction of the euro (Micossi, 2012). 
But what is the origin of this miracle that, interest rates on debts are declining in the times of the crisis and high public deficits? To explain it, we have to understand the payment system of the euro area, TARGET 2. In 2007, this system replaced the old Target version. The TARGET 2 major innovation is the settlement of international payments of smaller amounts below 50,000 €. This new system has become the most widely used system for the settlement of international payments between the member states of the euro area.

The most commonly used example to understand the functioning of TARGET cross-border transactions is usually referred to an Irish farmer who wants to buy a German tractor (Storbeck, 2011). As the Irish banking system faces a liquidity problem and the farmer wants a loan to buy a tractor, he goes to his Irish bank, say the Anglo Irish Bank, and this bank turns on the central Bank of Ireland, which is part of the European System of Central Banks. The Bank of Ireland can actually borrow money from the ECB via the marginal lending facility at a $1.5 \%$ interest rate. To ensure the ECB that the Irish central bank will balance its Target liabilities in the future, this loan is collateralized. The Bank of Ireland has to secure a loan with collateral securities of a specific quality defined by the ECB. The bank does not receive a loan of the $100 \%$ value of the collateral, but by the quality of security and its maturity is determined a "haircut". The height of the haircut is determined by the valuation of the ECB (ECB, 2011b, p. 47-50). It is interesting to note that the Management Board of the ECB reduced the quality demand for the collateral allowing counter parties to raise funds from the ECB much easier (ECB, 2012b). The ECB publishes a list of eligible assets accepted as a collateral that can be found on the ECB's website.

If the Anglo Irish Bank gets money from the ECB, the entire transaction is recorded on the balance sheet of the ECB. It is essential to note that these funds must come from another bank acting in this respect as a creditor, because if it was not a transfer of funds through Target from a liquid bank (e.g. German) to a less liquid Irish bank, the funds would have to be obtained by the ECB otherwise, e.g. through selling the foreign exchange and gold reserves, printing new money, or obtaining liquidity by issuing debt certificates. The countries affected by the crisis, especially their banks, have problems to borrow funds from other banks in the economy, so they receive funds through the Target system or through other programmes of the ECB (e.g. LTRO). So far it has worked as follows: a bank in other country actually provides liquidity via the ECB liquidity mechanism to the bank which currently can not get finance from the other banks in its own country.

A similar relation with commercial banks, two states and central banks can be observed, when a citizen wants to transfer money from one EU country to another. The following scheme demonstrates this situation. 


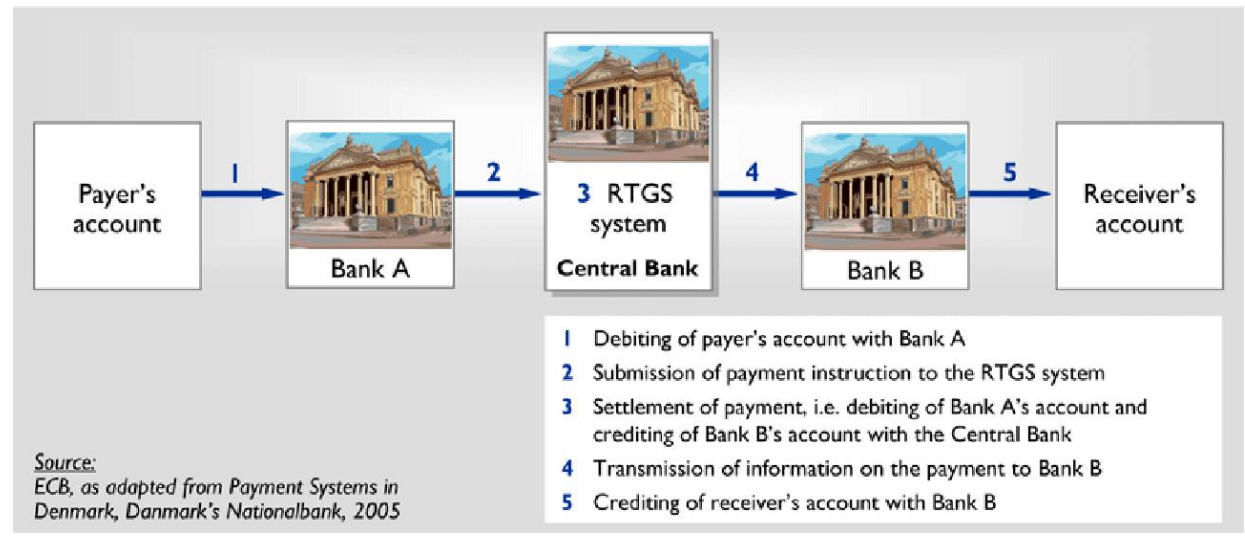

Source: ECB

There is a number of articles pointing out the details on accounting the operations to the balances of institutions participating in the payment system, as can be seen in the scheme. This process of accounting is very clearly described in the study by Bindseil and König (Jobst et al., 2012; Bindseil, König, 2011). The entire operation of the transfer from a bank in one country to a bank in other is processed through the Target 2 system. The original central bank (in the state of the sender) destroys funds from its own balance sheet and there is created an accounting enrolment in the balance of the central bank and the balance sheet of the commercial bank/s, that are beneficiaries of these funds. To avoid the whole system to collapse in case of a massive outflow of capital from the member states of the euro area due to the collapse of its banking system, the ECB has become a ,market maker of the last resort”.

The ECB actually replaced funds transfer which should work on the interbank market, but it does not. As shown by Abad with Löffler and Zemanek on the practical example of Germany and Ireland in the pre-crisis period, there was a boom in Ireland realized through the inflow of foreign capital. The major item of the Irish banking system's liabilities consisted of foreign deposits. However, once the crisis began, the owners moved their money out of the country. Foreign assets of German banks grew before the crisis, but this has changed after the fall of the Lehman Brothers and the share of foreign assets on the total balance has begun to decline. This means that the money invested abroad is returning back to Germany. If the ECB had not intervened by providing liquidity to the banks (using ELA, LTRO), we would have been 
victims of massive bank runs ${ }^{1}$, so there would have been a default of the economy due to capital outflows very well known from the currency crises. The ECB and other central banks act as mediators in the interbank market. This situation demonstrates a tremendous increase of the balance sheets of these central banks (Abad et al., 2011, p. 1-6).

Interesting in this context is a dispute among European economists about the real effect of the TARGET 2 imbalances on the economies of the eurozone member states. In this respect Germany, the Netherlands, Luxembourg etc. are creditors and the peripheral economies of Greece, Italy, Spain, Portugal and Ireland are debtors. This imbalance is confirmed by the following chart from the Institute of Empirical Economic Research (Osnabrück University, 2012).

Position of creditors and debtors by Target 2 GDP ratio measuring their real exposure in Target 2

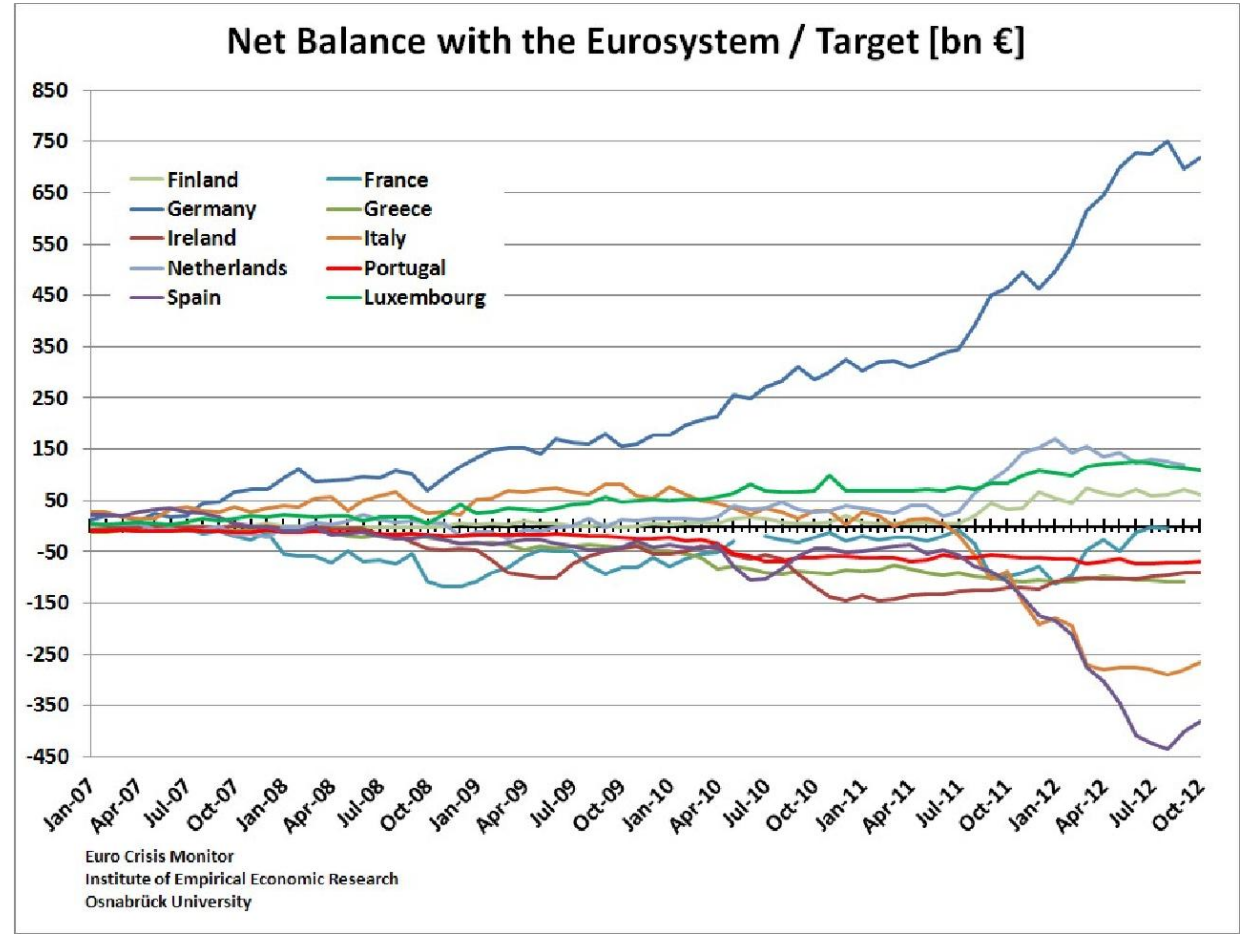

Source: Osnabrück University, Euro Crisis Monitor 2012

${ }^{1}$ Bank run is the situation, when depositors lose trust in the banking system and start to withdraw their deposits, which can lead to bank insolvencies. 


\section{The problem with potential losses from Target 2}

The question is how the system to settle the payments can make a loss, if the transfer of funds is covered by collateral? The Target 2 system can continue to operate in the settings it works in today, but it is undeniable that if the eurozone collapsed, this would not only hit the indebted countries (currency devaluation would cause the default of many entities that would not be able to meet its payment obligations, following the loss of tax revenue etc.) but also the TARGET participants acting as the suppliers of liquidity to the economic systems of the EU's peripheral countries. This was pointed out by the German economist Hans Werner Sinn in 2011 (Sinn, Wollmershäuser, 2012) and thus commenced a debate about the effects of the outstanding balances of Target 2 . The damage of creditors could be actually realized when a member state exits from the euro area. The transition to a new currency which would depreciate would cause the collateral, the commercial banks used to obtain liquidity from the ECB, to lose its value, so the ECB would have to bear the loss. The peripheral economies would not be able to repay all liabilities that have been increasing quickly especially since the start of the crisis. The central bank of the leaving state would virtually go bankrupt on its liabilities.

The situation is so dramatic that the exposure of the Bundesbank (as the biggest creditor) to other central banks is increasingly growing and it will probably continue. The item Sonstige Aktiva in the consolidated version of the Deutsche Bundesbank balance reached 755.7 billion euros. These are the real claims of the Bundesbank to Target 2 (Deutsche Bundesbank, 2012, p. 93). The liabilities of the Target 2 are shared between the member states by their share in the ECB capital. Slovakia with its $0,99 \%$ share is also responsible for the stability of the system, which is not actually even now under the control.

The bank deposits in the peripheral economies are still falling and moving outside these economies. People and corporations moved out of Greece, Portugal, Spain and Ireland, and according to the calculations by Bloomberg, this meant 326 billion euros during the last 12 months (Onaran, 2012). This is partly due to the German and French banks that decreased their exposure to the risky eurozone countries, including Italy, by around 100 billion euros. According to the statistics of the Banca d'Italia, the deposits of the non-resident banks in Italian banks fell from July 2011 to July 2012 by 50 billion euros (Banca d'Italia, 2012, p. 25). At the same time, the banks in the core eurozone countries got rid of government bonds of the peripheral economies, and the domestic banks increased their holdings of these securities. The trend of the exposure reduction of the core economies banks on the European peripheral economies is likely to continue. In the absolute numbers, the movements of the capital in the euro area are shown in the chart below. 
Balance of Target 2 in member states of the eurozone, 2009-2011

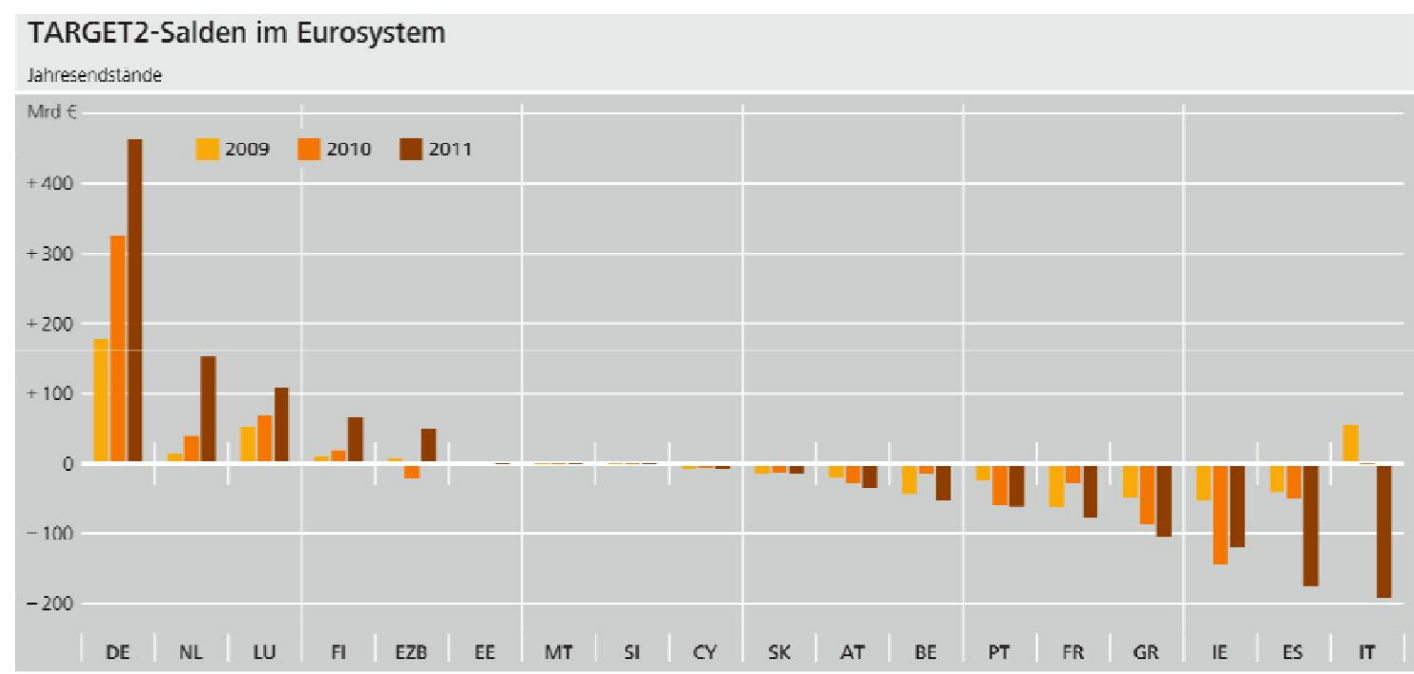

Deutsche Bundestounk

Source: Deutsche Bundesbank

The first chart of this study demonstrated the declining interest on 10-year bonds of the core eurozone economies. Even on some debt instruments with shorter maturities, there appear negative returns, as could be seen in Germany during the 2-year Bund emission (Barth, 2012). This means that investors are moving their money to the safer economies and are even willing to pay for depositing their funds into the safer German Bund at the expense of the potential risk of default that could threaten them as the owners of Greek or other risky securities. The following table shows how many thousands of euros are required to insure a 5-year government debt of 10 million euros in the selected economies and for comparison in the USA (5-year CDS).

Sovereign 5-Year Credit Default Swaps

\begin{tabular}{|l|l|l|l|l|l|l|c|l|}
\hline Country & Greece & Ireland & Italy & Portugal & Spain & Slovakia & Germany & USA \\
\hline sovereign CDS & 12765.09 & 320.64 & 357.63 & 499.94 & 391.42 & 140.85 & 54.18 & 33.04 \\
\hline
\end{tabular}

Source: Author and CNBC in October 2012

In Greece, a 5-year insurance of 10 million debt costs 12.7 million euros! This can actually be verified with the annual Target 2 report (ECB, 2011, p. 10). There was a significant positive balance in the Target far exceeding the budget surplus of the core economies which clearly demonstrates that the capital flows to these countries are at the expense of the peripheral economies 
capital. In this context, we can not consider negative balances being caused only by the current account deficits of the peripheral economies which also have problems with export (De Gauwe, Ji, 2012b; Buiter et al., 2011). Deficits and surpluses are not the major source of volatility in the Target 2 balances between the euro area countries. To resolve this unfortunate situation, the balance should be improved through the reinstatement of confidence in the domestic markets of the peripheral economies, which goes hand in hand with the return of their competitiveness.

In several studies, including the one by Hans Werner Sinn, the emphasis is put on the necessity of reaching a balanced current account by austerity, possibly by reduction of salaries. The reduction of inputs should result in an increase of competitiveness of these economies which have lived beyond their means. On the one hand, we cannot argue that the growth of unit labour costs were significantly higher in the peripheral economies than in Germany, but what currently affects the peripheral economies the most is a rather stronger euro.

According to Zsolt Darvas (Darvas, 2012), the Greek export's share to other euro area countries in the total export is only $24 \%$. In Italy it is around $29 \%$ and $53 \%$ in Spain. We are most worried about these countries, either because they are actually in default (Greece), or they are too large for an efficient rescue by the ESM. ${ }^{2}$ We believe that a massive devaluation of the euro would at least partially replace the potential devaluation when leaving the eurozone and could help these states. Of course, this would impact the price levels (HCPI), if the peripheral economies had not eased their price regulation achieving a greater price flexibility (Wolff, 2012). In this case, the aggregate demand in the peripheral economies decreases because of the growth of unemployment and we face a consecutive lowering of prices. Even if the devaluation of the Euro would cause a higher inflation in the core economies, harmonized inflation could be achieved by deregulated prices as the average, set approximately to $2 \%$ by the ECB. Or in other words, lower inflation in Italy and higher one in Germany should help balance the eurozone. The first objective of the ECB is to maintain a stable price level. Providing a higher inflation level, the ECB would proceed to a restrictive monetary policy which would hurt the peripheral economies even more.

The problem with capital flows into the safer economies occurred when the debt crisis had broken out and banks stopped trusting each other as reflected in the most obvious indicator of tensions in the interbank market the Euribor-

\footnotetext{
${ }^{2}$ Assuming that the ESM size will not increase either through a further guarantee and additional capital at request of Member States, or in the form of leverage if the ESM has been granted a banking license from the ECB.
} 
Eonia swap spread. The decrease in spreads after 21 December, 2011, when the ECB launched the long-term refinance operation (LTRO) programme to supply liquidity to banks (Angeloni, Wolff, 2012) is worth noticing.

Euribor-Eonia swap spread

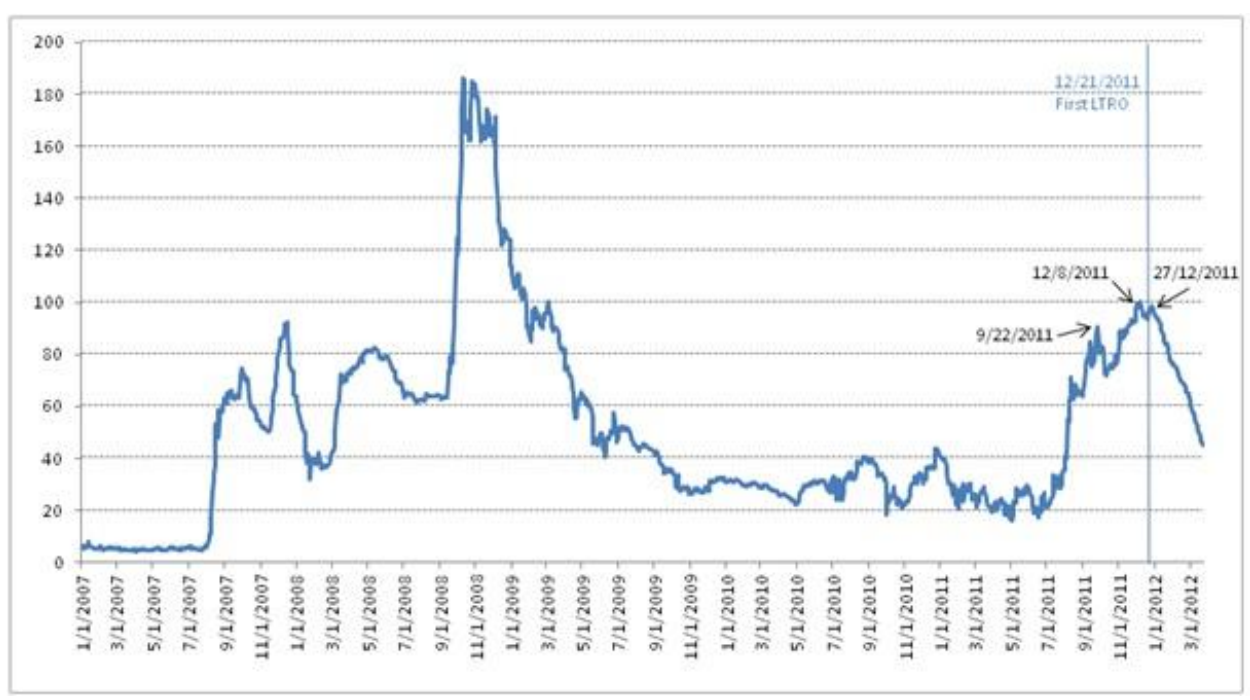

Source: Angeloni, Wolff 2012

The LTRO is a collateralized three-year loan from the ECB to the commercial banks in Europe. The interest rate is set at 1\% per annum. This cheap money supplied to the banks is expected to be used to cover a part of their liquidity problem associated with bad investments and in the fight against the bank runs (The European System of Central Banks uses also the ELA). The second round of the LTRO was accomplished in March 2012. The first two rounds of the liquidity supply reached more than 1,000 billion euros. The peripheral economies are attacked by declines in the private capital inflows and these outages are being replaced by the LTRO (Pisani-Ferry, Merler, 2012). Currently, the amount of the item 5.2 Longer-term Refinancing Operations of the ECB is over 1,058 billion euros (ECB 2012) and these funds are expected to be used to buy government bonds. On the one hand, it is positive because it could ease the pressure on the bond's interest rates; on the other hand, an even greater perverse link between the state and commercial banks that already hold more than $20 \%$ of sovereign bonds in Greece, Portugal, Spain and Germany, has been created (Pisani-Ferry, Wolff, 2012, p. 4).

The banking union should help to break the correlation between the risk premium of government securities and those of the commercial banks. When a 
bank in the country of its origin has a problem, this affects the outlook and risk of the country, and, conversely, the country in trouble can negatively influence the credibility of the domestic financial institutions. So the removal of a territorial determinant is necessary.

Europe suffers from a banking crisis because banks are weak, the debt crisis (mainly in the peripheral economies) and as well crisis of growth and competitiveness (Shambaugh, 2012). The weakness of banks can be verified through the Tier 1 capital ratio $^{3}$ which measures the risk of banks (Schoenmaker, Gros, 2012, Annex A2), or also by the amount of liabilities of the banking sector with regard to the bank's resident country's GDP. The 2008 data show the size of such liabilities in Ireland reaching more than $600 \%$ of the GDP. Therefore it is logical that Ireland was virtually going bankrupt when the venture capital shifted to the safer countries out of Ireland and Irish banks got into trouble due to the bursting of the housing bubble. Likewise, in the Netherlands and Belgium the banking sector liabilities reached almost $500 \%$ of their GDP. The euro area average was around $250 \%$. This should be compared with the average $80 \%$ of the GDP government debt in the euro area (De Grauwe, 2011, p. 4).

If depositors cash their deposits from a less liquid bank, this bank must either borrow in the interbank market or from the central bank, or it is forced to sell its assets to meet their clients' interests. But this mechanism of getting rid of bonds, mortgages and other assets actually leads to the pressure on the prices of those assets. So the liquidity crisis is reflected in the increase of the interest rate on sovereign bonds where the bank resides, and in this way the liquidity crisis evolves into the debt crisis. Perhaps it is not necessary to mention the effect of bank deposits guarantees which further supports the link between the private banks and the state (EU 2009). The ELA (emergency liquidity assistance) was created to provide liquidity to banks through the European System of Central Banks which is discussed below, but firstly we conclude the issue of potential losses from the Target 2 .

The ECB correctly remarked that until the whole system works with all members of the euro zone, asymmetrical balances in the Target 2 between countries do not represent any significant risk (Randow, 2012). Relatively to its domestic commercial banks, the central bank is in the paradoxical role of a debtor. Hans Werner Sinn pointed out the potential losses that would be incurred if writing off assets from the balance of the ECB (providing an exit of a member state), would have to be paid by the Germans and other taxpayers in order to balance the ECB's balance sheet. This view was opposed by some

${ }^{3}$ The Tier 1 capital ratio is the ratio of a bank's core equity capital to its total riskweighted assets (RWA). 
authors. Karl Whelan notes that in the fiat money system where the central bank does not guarantee the convertibility of the currency into gold, it is not necessary that the amount of assets equals to liabilities. So the central bank assets may fall below the value of its liabilities. The balance may indicate that the central bank is insolvent without having an impact on the currency flow (Whelan, 2012). The central bank's accounts are subject to audit, so if the assets fall below the liabilities, the central bank should be recapitalised through the fiscal transfers. Hence, if there was an exit of a member state from the euro area which would not be able to settle its liabilities arising from the TARGET 2 as a whole and the eurozone would not fall apart, it would be probably really inevitable to balance the ECB's balance sheet through fiscal transfers from the taxpayers.

A completely different situation would arise if the euro area as a whole falls apart. The Deutsche Bundesbank would then reintroduce the Deutsche Mark (in analogy to the National Bank of Slovakia - the Slovak crown) and Germany could gradually balance its balance sheet with profits from operations of the Central Bank, or would just accept this imbalance. Indeed, in some cases, as with the Central Bank of Chile and the Czech National Bank ${ }^{4}$, it is possible to operate with an unbalanced balance sheet (Bijlsma, Lukkezen 2012; ČNB, 2012). But there will always be the option to cover the losses from the Target, providing further existence of the eurozone, by taxes from tax payers of the member states in proportion to their share in the ECB's capital. Currently, the Target 2 liabilities of the peripheral economies are relatively high.

Target 2 liabilities of peripheral eurozone economies in billions of euros

\begin{tabular}{|l|c|}
\hline Country & Target 2 liability \\
\hline Spain & 423 \\
\hline Italy & 280 \\
\hline Greece & 105 \\
\hline Ireland & 103 \\
\hline Portugal & 73 \\
\hline Total & 984 \\
\hline
\end{tabular}

Source: Bijlsma, Lukkezen 2012

Felix Salmon believes that nothing serious will occur if all 17 members of the euro area hold together (Salmon, 2012). Greece would not be able to repay

${ }^{4}$ I would notice the item number 10 in the liability side of the ČNB balance sheet called Profit and losses from previous periods, where ČNB shows the loss of more than 126 billion Czech crowns, but it does not affect the credibility of the Czech currency. 
105 billion euros of liabilities arising out of balance in case of unmanaged bankruptcy. But, as Salmon states, the ECB has more than 400 billion euros in gold, so such a loss would be able to bear. This is true, but what would happen in the event that also Spain or even Portugal went bankrupt? William R. Cline of the Peterson Institute (Cline, 2011, p. 5; Cline, 2012, p. 17) estimates in his debt sustainability projections that the Spanish public debt should stop somewhere at $90 \%$ of the GDP, but it may be even worse as it was with the Greek debt projection of 2011 that already appears to be unrealistic, although his work resulted from the IMF and the OECD statistics.

In the case of such a scenario Salmon responds that the ECB would print new money. Basically, we can agree because if there was an exhaustion of surplus liquidity from creditor's banks and the Target 2 functionality was threatened, the ECB would have to accede to the alternative policy and print new money. Whereas these operations were not sterilized, such a procedure would increase inflation in the euro area, which would correspond to the ,debt monetization" in the form of the Target 2 liabilities. The member states can get rid of the debt burden by increasing taxes to cover the losses through fiscal transfers, or by a second method where losses are paid by all member states in the form of inflation. That is the argument that Germany or other member states would actually lose nothing if the eurozone breaks up (in terms of losses from the Target). But one must not forget that Germany hardly wants to leave the Monetary Union and jeopardize the revaluation of its own currency and the return to deficit balances of the current account that Germany experienced before the creation of the European monetary union. It is likely that Germany will try to maintain a smaller euro area where the potential to cover the losses exists. If some euro area member states left the eurozone, the euro would not be replaced by a new euro currency. The member states of the eurozone would have to continue in the monetary union with the existing losses.

The ECB does not have to resort to printing of money yet because although there are increasing Target 2 claims of the Bundesbank, the German central bank receives funds through the central bank deposits of the domestic German banks (and other banks of creditor states) having surplus liquidity due to the capital inflow from the peripheral economies. It is questionable what would happen if the German banks stopped depositing their liquidity with the central bank. This is actually the scenario which Hans Werner Sinn concerns about.

The first scenario is that the Target needs are covered by the supply of capital from the German banks (Buiter et al., 2011b, p. 6-7). Increased Target claims of the Bundesbank are covered by higher liabilities in the balance sheets of the German banks towards the non-residents. Again, the contribution of Paul De Grauwe is dealing with the situation when Germany is leaving the euro area (not that Germany remains in the euro zone). He suggests that the problem with 
the damaged balance sheets on the assets side could also be sorted out by the return to a new German Deutschmark. But the non-residents from the bankrupted countries (devaluation of their new home currency after the exit from the eurozone) would prefer to exchange money for a strong Deutsche Mark rather than for the devalued currency. Due to the exchange of euros for non-residents, this would lead to an appreciation of the Deutsche Mark and to the increased inflation in Germany. However, this could be avoided by declaring that Germany would eventually exchange the euro for the Deutsche Mark only to German citizens (De Grauwe, Ji 2012b, p. 11-13).

A clear signal that Germany in case of the eurozone break-up would not exchange the euro for the Deutsche Mark to the non-residents could discourage the non-residents from levying money and saving them in Germany. This could at least partly help to stabilize the financial flows between countries. If other member states in the position of creditors also declared the same, it remains unclear whether people in the peripheral economies would start to purchase more foreign currencies, such as the USD. However, this would at least partially help to strengthen the dollar and it would have a positive effect in favour of the peripheral economies. But there is a risk that we would face higher inflation because of the overpriced imports to the EU (especially in relation to the price of crude oil).

\section{Emerging liquidity assistance (ELA), Securities Market Program (SMP) and Covered Bonds Purchase Programmes (CBPP)}

The ELA can be created by the national central banks for the provision of liquidity to less liquid banks that have problems to obtain liquidity, for example due to the worse collateral quality. The ELA enables acceptance of the collateral which is not receivable by the Eurosystem. The State National Bank where a troubled bank is situated proposes the height of the ELA that has to be approved by the 23-member Governing Board of the European Central Bank. The interest rate of this loan is higher than the marginal lending facility rate, and other conditions are set. Although the provision of the ELA is de facto liability of the Eurosystem, this type of exposure is not regarded as Eurosystem's liability but as the requesting national central bank's exposure. This should protect the Eurosystem against a loss, but in fact this type of assistance is considered being secured against default only by far the National central bank is able to absorb a prospective loss on default or until a country is able to cover the loss. So there is not such a guarantee when the country is virtually bankrupt (Greece) or nearly insolvent (Ireland, Portugal) (Buiter, 2012, p. 3-5).

Currently, it is difficult to ascertain exactly the height of the ELA approved by the ECB which did not publish the ELA data separately till 20 April, 2012. 
This information relates to other assets. The ECB transferred the ELA in April 2012 under the item "Other claims on the euro area credit institutions in euros". When the reclassification was published it was revealed that the total amount of the provided ELA was 121 billion euros. Under "Other claims on the euro area credit institutions in euros" not only the ELA is hidden, but also standard shortterm operations to supply liquidity. Both the ECB and central banks are seeking to obscure the exact ELA numbers because of the fear of public reaction that could lead to a further tension in the market and runs on banks. By estimates, from 211 billion of "Other claims on euro area credit institutions", the ELA represents around 160 billion euros. This sum is allocated as follows: 106 billion to Greece, around 41 billion to Ireland, and 10 billion to Cyprus (Milligan, 2012). Especially Greece whose exit from the euro area is currently being discussed represents a risk, because the ELA loan is guaranteed by the National Bank of Greece (actually covered by a collateral that is of inferior quality). Finally, the inability to settle the balance of the ELA will result in further damage of the ECB's assets.

The ECB created the Securities Market Programme on the 9 May, 2010, which was intended to ensure a smooth conduct of monetary policy of the EU, but in reality it was created to help the states that have to borrow at high interest rates under the pressure of international markets. The ECB may purchase the securities as referred to in Article 18 of the Protocol on the Statute of the European System of Central Banks and the European Central Bank accepting that according to Article 21, the ECB must not buy debt securities directly from public or private entities. The SMP can be used as a tool of monetary policy but only in the secondary market (De Grauwe, 2011, p. 11). In total, the Securities Market Programme reached approximately 209.5 billion euros to 5 October, 2012 (ECB, 2012c). It is hard to estimate what kind of securities is contained in this programme's portfolio

Citi Investment Research and Analysis attempted to assess it in February 2012 when the SMP programme was of almost 219 billion (share by the countries: Greece and Spain $18-19 \%$, Portugal $10 \%$, Ireland $8 \%$, and Italy $45 \%$ ). Similarly, as for the programmes of the covered bond purchases, we do not have accurate estimates of the portfolio structure, although these bonds are doubly covered by the underlying asset and by the institution itself. If these institutions go bankrupt (e.g. Spanish or Greek banks), the notional loss is not negligible. There were two CBPP programmes until now, with a total size of 70 billion euros (Buiter, Rahbari, 2012, p. 19-22). Finally, potential losses connected with the exit from the euro zone could also arise from the main refinancing operations (MROs), as long as the collateral is of low quality and the bank would not be able to repay its obligations. The MRO-appropriation reaches 103 billion euros (ECB, 2012). 
The ECB announced the launch of a new three-year programme to buy bonds labelled Outright Monetary Transactions (OMT) on 6 September, 2012, and it also provided details of this programme. One of the conditions to the realize OMT operations is the involvement of the country whose bonds are bought in the EFSF or ESM programme with the option to buy bonds through the EFSF / ESM on the primary market. The purchases have no quantitative limits. The ECB will operate in the secondary market and will focus on the bonds with shorter maturities up to three years for which, unlike the previous programme, it will not apply seigniorage, and to avoid invoking inflation, purchases will be sterilized (Saha, Kessler, 2012). So we will have a look at the liabilities of the peripheral economies in comparison with their sovereign debt and the size of deposits in banks.

\section{Liabilities of peripheral economies in billions of euros and bank deposits and official loans}

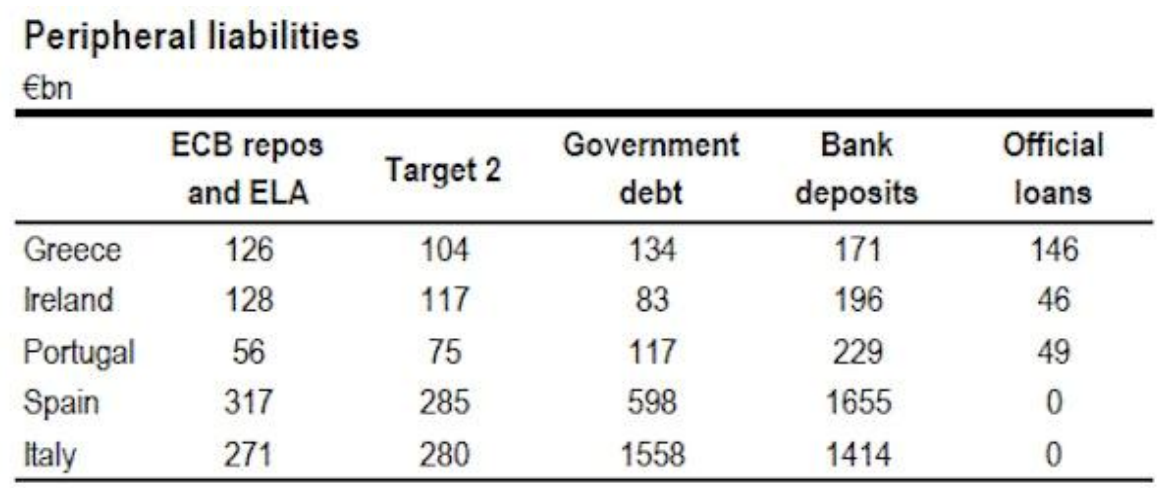

Source: Auerback 2012

This table is an estimation from May 2012. As you may have noticed in the previous chart, the official size of the Target 2 liabilities of Spain is 420 billion euros. ${ }^{6}$ But this chart is sufficient to illustrate the real state of the European Union's exposure via official programmes to the peripheral economies.

\footnotetext{
${ }^{5}$ Seniorage means that if there is a default, firstly the interests of senior bond holders will be satisfied. This is quite risky for private investors. Practically in the application of the seniorage, private investors are even less motivated to invest along with the mechanisms of the EU, because they are disadvantaged. After the satisfaction of the EU's interests, the private investors interests satisfaction could be very low due to the limited remaining funds. Somebody has to bear the loss and in this case it is mainly the private investor, if the sovereign goes bankrupt.

${ }^{6} \mathrm{EFSF} / \mathrm{ESM}$ is also expected to provide up to 100 billion euros for recapitalization of
} 
Marshall Auerback reported that even solvent banks might have problems and become insolvent as far as people cease to trust the safety of their deposits and massively withdraw funds from their bank accounts. It accrues from the above table that while banks have experienced a run, the liquidity they had lost was returned in form of repurchase operations of the ECB, ELA, and also through two rounds of the LTRO (Auerback, 2012). The Greeks had withdrawn at least $40 \%$ of the original deposits in their domestic banks. In case of Spain, we noticed an increase in the negative Target 2 balance reaching up to 420 billion euros ${ }^{7}$ just three months after the 280 billion estimate from May. This trend may continue in other depressed economies as well so that the total Target 2 liability of all five peripheral countries might achieve up to 3,000 billion euros. The European systems and programmes maybe will have to replace the domestic deposits to avoid the system to collapse. Germany would certainly take a very negative attitude towards this scenario. We believe this could happen after the start of a domino effect after the exit of Greece from the eurozone.

\section{The proposal for banking union}

Assuming a managed exit of Greece from the euro area would mean a creation or application (now non-existent) of some exit clause of the member states from the euro zone. Regardless of Greece being an exception, financial markets and not governments were undisciplined, as we noted when having compared the increase of bank's debt against the average indebtedness of governments. If a mechanism for controlled bankruptcy of a country were created, it would actually address the symptom of the financial crisis (the deepening problems of public finances) and would not address the cause that lies in the financial sector. If such a clause is created, it will support speculative dynamics in the Union, and we will return to the times of the EMS from the 1980s and 1990s. If investors felt that a country had a problem, and it might not even be due to its high public debt, they would sell their securities portfolio and the country would be forced to leave the monetary union. Possibly later, after the improvement in financial situation, the country would return to the eurozone.

Spanish banks. Spain itself did not request a loan from European Commission, but this possibility is not ruled out in the future.

${ }^{7}$ Certainly, the negative balance of Target arises also from the balance of payments deficits, when in Spain are generated trade deficits and in Germany surpluses. This is recorded in Target 2 balance, but these enormous differences in Target 2 are minimally determined by deficits. The main driving element of the increase in liabilities of the Target are speculative movements of capital from indebted countries to safer destinations. 
We should not underestimate the potential risk of the conversion of the monetary union into ,,The European Monetary System 2" (De Grauwe, 2010).

Now it is clear why the eurozone needs banking and probably an economic, fiscal and maybe even political union if we want the euro to survive. The banking union is not going to be established only for better centralized supervision of the banking sector in the member states by Brussels, but mainly because we have to break the perverse link between the sovereigns and the banks, and to restore the confidence of depositors in the banks. People should be ensured that their money can be saved at home and should not worry about losing them, so the European Deposit Guarantee is to be implemented. Certainly, the actual ability to cover potential losses through the European Fund for deposits in truly big problems could be a matter of dispute, but the effect should be the restoration of trust in the domestic banks (Schoenmaker, Gros, 2012).

The European Commission Communication to the European Parliament and the Council admits this possibility and openly talks about a common mechanism for the resolution of banks and guarantee deposits as one of the next steps to create a banking union (European Commission, 2012a). The current proposal of the European Commission being in the approval process (European Commission, 2012e) does not contain a proposition for a common European deposit protection fund. If sovereigns have problems with covering the loss from their national guarantee fund, they could, to a limited extent, borrow from other state's guarantee fund (Carmassi et al., 2012; European Commission, 2012c). The European Commission inquires the European Parliament and the Council to finalize the necessary legislation to create a banking union by the end of this year. Today, this request seems to be unrealistic.

A single mechanism for the supervision of the banks in the eurozone that the ECB will be accountable for (licensing credit institutions, supervising capital requirements, etc.) is considered as a positive first step toward a functioning banking union. To create a single surveillance mechanism should be a prerequisite for the direct recapitalization of banks through the ESM. The European Banking Authority should develop a uniform set of measures for the supervision in order to maintain the integrity of the single market, a ,single rulebook". The proposal mentions also a possibility of setting up a resolution bank of the last resort to avoid rescuing the troubled banks through taxpayer's money. Firstly, shareholders and creditors of the troubled banks should bear the costs. Financing should be made through special funds that would receive money from banks in proportion to their size and risk profile. These funds should reach $1 \%$ of the covered deposits value in ten years (European Commission, 2012b; European Commission, 2012d). The analysis of the new 
architecture of a banking union would be beyond the scope of this paper. For details, see the aforementioned references.

\section{Conclusion}

The Financial Policy Institute (IFP) of the Slovak Ministry of Finance presents in its report (Bugyi, Franek, 2012) that Greek bankruptcy would cost Slovakia 723 million euros. The second report of the IFP refers to a potential GDP decline of around 4\% in Slovakia in 2013 as another important negative impact (Machlica, Tóth, 2012) of the Greek exit scenario. While the first mentioned work highlights the potential risks of the balance of payments arising from a potential loss, the EFSF / ESM is identified as the main source of losses. The Slovak share in this mechanism is $1.0644 \%$.

This study did not attempt to make an accurate calculation of the costs for Slovakia in case of the country exit from the euro area, or the total bankruptcy of the common European currency project. The aim was to clarify the third component of the total loss that Slovakia would experience in relation to the Target 2, ELA, SMP / OMT, MRO and CBPP. Nobody can exactly quantify what would be the total loss for the Slovak Republic. These losses would be calculated in relation to the share of Slovakia ${ }^{8}$ in the ECB capital and could be even higher than the actual loss from the EFSF / ESM. All 17 member states of the euro area would share the loss according to the adjusted ECB capital key.

\footnotetext{
${ }^{8}$ Losses and profits from the Eurosystem regarding ECB's operations are shared according to the share in the ECB's capital. It is laid down in the Protocol on the Statute of the European System of Central Banks and the ECB in Articles 33.1 and 33.2 (Protocol (No 4) on the Statute of the European System of Central Banks and of the ECB).
} 
Adjusted share of national central banks in ECB's capital

\begin{tabular}{|l|c|}
\hline \multicolumn{1}{|c|}{ National Central Bank } & Adjusted Capital Key \% \\
\hline $\begin{array}{l}\text { Nationale Bank van Belgï̈ /Banque } \\
\text { Nationale de Belgique }\end{array}$ & 3,47 \\
\hline Deutsche Bundesbank & 27,06 \\
\hline Eesti Pank & 0,26 \\
\hline Central Bank of Ireland & 1,59 \\
\hline Bank of Greece & 2,81 \\
\hline Banco de España & 11,87 \\
\hline Banque de France & 20,32 \\
\hline Banca d'Italia & 17,86 \\
\hline Central Bank of Cyprus & 0,2 \\
\hline Banque centrale du Luxembourg & 0,25 \\
\hline Central Bank of Malta & 0,09 \\
\hline De Nederlandsche Bank & 5,7 \\
\hline Oesterreichische Nationalbank & 2,78 \\
\hline Banco de Portugal & 2,5 \\
\hline Banka Slovenije & 0,47 \\
\hline Národná banka Slovenska & 0,99 \\
\hline Suomen Pankki- Finlands Bank & 1,79 \\
\hline Total & 100 \\
\hline
\end{tabular}

Source: Author and ECB

If the member states gradually exited from the euro area and there was a loss, Slovakia's share in the ECB would increase. Every other exit of a country would be even more expensive, provided that Slovakia remained in the eurozone.

The actual level of loss depends on whether the eurozone would survive or completely break up, how many states would possibly leave it, and in what way. A complete disintegration of the euro area and return to our former currencies could help to solve the damage of either the assets or liabilities of the central banks, but the loss of the economic benefit that the monetary union clearly brought would be considerable. We have already outlined that the exit of one member state could trigger a domino effect and we would probably consider a loss resulting from the EFSF / ESM as a smaller piece of pie. Although the ELA loss should be borne by the National Central Bank, the ELA can cause damage to the ECB's balance sheet as well. One of the most apocalyptic studies on why the eurozone should not disintegrate is a comment by Anders Aslund (Aslund 2012). We hope that a similar scenario as in other 
former monetary unions whose member states hardly bore their break-up will not be the eurozone's destiny.

Slovakia should maintain a clear position and express its support for the common project of the euro, but at the same time we should be aware of the exposure to the mentioned mechanisms that is increasing and this trend is likely to continue. The raising doubts about the current European policy in the economic and monetary area would not have a positive effect on the economy of the Union. In our opinion, there is no other way because the situation has significantly changed since 2010, and if we want to avoid losses as a country, we will probably have to take the additional risk associated with the provision of additional funds to the peripheral economies. At the same time, we should strive to strengthen the control mechanisms of the Union, whether in the field of supervision and regulation of the banking sector, or in the budgetary surveillance of the member states. The proposals introducing eurobonds ${ }^{9}$ appear promising, although they will require (at least the more acceptable proposals) a creation of a fiscal union that should ultimately lead to the creation of a political union as the highest level of an integration.

Some authors think that the markets are about faith in financial markets and in stability and safety. The authors tend to speak that the first rule of the ELA is that it is never mentioned. It would be interesting to watch the European economy if we stopped talking about the eurozone crisis. The crisis would probably not be completely solved but we would surely witness less runs on banks and speculative flows between the European economies, and this text would not leave such negative impression.

\section{REFERENCES}

Abad, J. M., Löffler, A., Zemanek, H. Target 2 Unlimited: Monetary Policy Implications of Asymmetric Liquidity Management within the Euro Area [online]. c2011, updated in July 2011 [cit. 2012-10-15]. Available: www.ceps.eu/ceps/dld/5904/pdf.

Angeloni, Ch., Wolff, G. B. Are banks affected by their holdings of government debt? [online]. c2012, updated in March 2012 [cit. 2012-10-15]. Available at: www.bruegel.org/download/parent/717-are-banks-affected-by-their-holdings-ofgovernment-debt/file/1564-are-banks-affected-by-their-holdings-of-governmentdebt/.

9 European Commission. (2011) GREEN PAPER on the feasibility of introducing Stability Bonds [online] updated on the 23rd of November 2011 [cit. 2012-10-15]. Available at: eur-lex.europa.eu/LexUriServ/LexUriServ.do?uri=COM:2011:0818:FIN: EN:PDF. 
Aslund, A. Why a collapse of the Eurozone must be avoided [online]. c2012, updated on the $21^{\text {st }}$ of September 2012 [cit. 2012-10-15]. Dostupné z:

http://www.voxeu.org/article/why-collapse-eurozone-must-be-avoided-almost-anycost.

Auerback, M. Anatomy of a Bank Run [online]. c2012, updated on the $23^{\text {rd }}$ of May 2012 [cit. 2012-10-15]. Available at:

http://www.social-europe.eu/2012/05/anatomy-of-a-bank-run/.

Banca d'Italia. Supplements to the Statistical Bulletin: Monetary and Financial Indicators [online]. c2012, updated on the $7^{\text {th }}$ of September 2012 [cit. 2012-10-15]. Available at: www.bancaditalia.it/statistiche/stat_mon_cred_fin/banc_fin/pimsmc/pimsmc12/sb4 5_12/en_suppl_45_12.pdf.

Bartha, E. 2012. Negative Yield on German 2-Year Note. US: The Wall Street Journal. Available at: http://online.wsj.com/article/SB10000872396390444330904577535102520070554. html.

Bijlsma, M., Lukkezen, J. Should we worry about Target2 imbalances? Why Central Bank negative equity does and doesn't matter [online]. c2012, updated on the $3^{\text {rd }}$ of September 2012 [cit. 2012-10-15]. Available at: http://www.bruegel.org/nc/blog/detail/article/879-should-we-worry-about-target2imbalances-why-central-bank-negative-equity-does-and-doesnt-matter/.

Bindseil, U., König, P. J. The economics of TARGET2 balances [online]. c2011 [cit. 2012-10-15]. Available at: sfb649.wiwi.hu-berlin.de/papers/pdf/SFB649DP2011035.pdf.

Buiter, W. Is the Eurozone at Risk of turning into the Rouble Zone? [online]. c2012, updated on the $9^{\text {th }}$ of February 2012 [cit. 2012-10-15]. Available at: willembuiter.com/roublezone.pdf.

Buiter, W., Rahbari, E. Looking into the Deep Pockets of the ECB [online]. c2012, updated on the $27^{\text {th }}$ of February 2012 [cit. 2012-10-15]. Available at: http://blogs.r.ftdata.co.uk/money-supply/files/2012/02/citi-Looking-into-the-DeepPockets-of-the-ECB.pdf.

Buiter, W. Rahbari, E., Michels, J. Making sense of Target imbalances [online]. c2011, updated on the $6^{\text {th }}$ of September 2011 [cit. 2012-10-15]. Available at: http://www.voxeu.org/article/making-sense-target-imbalances.

Buiter, W., Rahbari, E., Michels, J. (2011b) TARGETing the wrong villian: Target 2 and intra-Eurosystem imbalances in credit flows [online]. c2011, updated on the $9^{\text {th }}$ of June 2011 [cit. 2012-10-15]. Available at: www.willembuiter.com/originalsinn.pdf.

Bugyi, E., Franek, J. Grécky bankrot by verejné financie Slovenska mohol stát' 723 miliónov eur [online]. c2012, updated on the $8^{\text {th }}$ of June 2012 [cit. 2012-4-15]. Available at: www.finance.gov.sk/Components/CategoryDocuments/s_LoadDocument.aspx?cate goryId $=8238 \&$ documentId $=7366$.

Carmassi, J., Di Noia, C., Micossi, S. Banking union: A federal model for the European Union with prompt corrective action [online]. c2012, updated on the $20^{\text {th }}$ of September 2012 [cit. 2012-10-15]. Available at: 
http://www.voxeu.org/article/banking-union-federal-model-european-unionprompt-corrective-action.

Cline, W. R. Sovereign Debt Sustainability in Italy and Spain: A Probabilistic Approach [online]. c2012, updated in August 2012 [cit. 2012-10-15]. Available at: www.iie.com/publications/wp/wp12-12.pdf.

Cline, W. R. Sustainability of Greek public debt [online]. c2011, updated in October 2011 [cit. 2012-10-15]. Available at: www.piie.com/publications/pb/pb11-15.pdf.

Connolly, K. Germany's highest court approves creation of euro rescue fund [online]. c2012, updated on $12^{\text {th }}$ of September 2012 [cit. 2012-10-15]. Available at: http://www.guardian.co.uk/world/2012/sep/12/german-court-euro-rescuefund? newsfeed $=$ true.

ČNB. Bilance $\check{C} N B v$ mil. Kč [online]. c2012, updated on the $20^{\text {th }}$ of September 2012 [cit. 2012-10-15]. Available at: http://www.cnb.cz/cs/o_cnb/hospodareni/dekadni_bilance/cnb_bilance.html.

Darvas, Z. Intra-euro Rébalancing is Inevitable, but Insufficient [online]. c2012, updated in August 2012 [cit. 2012-10-15]. Dostupné z:

www.bruegel.org/download/parent/747-intra-euro-rebalancing-is-inevitable-butinsufficient/file/1607-intra-euro-rebalancing-is-inevitable-but-insufficient/.

De Gauwe, P., Ji, Y. (2012b) What Germany should fear most is its own fear: An analysis of Target 2 and current account imbalances [online]. c2012, updated on the $12^{\text {th }}$ of September 2012 [cit. 2012-10-15]. Available:

www.ceps.eu/ceps/dld/7280/pdf

De Grauwe. A mechanism of self-destruction of the eurozone [online]. c2010, updated on the $9^{\text {th }}$ of November 2010 [cit. 2012-10-15]. Available at: www.ceps.eu/ceps/dld/3894/pdf.

De Grauwe, P. The European Central Bank: Lender of Last Resort in the Government Bond Markets? [online]. c2011, updated in September 2011 [cit. 2012-10-15]. Available at: http://www.cesifo-group.de/portal/page/portal/DocBase_Content/WP/WPCESifo_Working_Papers/wp-cesifo-2011/wp-cesifo-2011-09/cesifo1_wp3569.pdf.

De Grauwe, P., Ji, Y. What Germany should fear most is its own fear [online]. c2012, updated on the $18^{\text {th }}$ of September 2012 [cit. 2012-10-15]. Available at:

http://www.voxeu.org/article/how-germany-can-avoid-wealth-losses-if-eurozonebreaks-limit-conversion-german-residents.

Deutsche Bundesbank. Monatsbericht-August 2012 [online]. c2012, updated in August 2012 [cit. 2012-10-15]. Available at:

www.bundesbank.de/Redaktion/DE/Downloads/Veroeffentlichungen/Monatsbericht e/2012/2012_08_monatsbericht.pdf?_blob=publicationFile

Directive $2009 / \overline{14} / \overline{\text { EC }}$ of the European parliament and of the Council of 11 March 2009 amending Directive 94/19/EC on deposit-guarantee schemes as regards the coverage level and the payout delay (Official Journal of the European union, L 68/3, 13. 3. 2009).

ECB. Consolidated financial statement of the Eurosystem as at 21 September 2012 [online]. c2012, updated on the $21^{\text {st }}$ of September 2012 [cit. 2012-10-15]. Available at: http://www.ecb.europa.eu/press/pr/wfs/2012/html/fs 120925.en.html. 
ECB. ECB takes further measures to increase collateral availability for counterparties [online]. c2012, updated on the $22^{\text {nd }}$ of June 2012 [cit. 2012-10-15]. Available at: https://www.ecb.int/press/pr/date/2012/html/pr120622.en.html.

ECB. Guideline of the ECB of 20 September 2011 on monetary policy instruments and procedures of the Eurosystem (ECB/2011/14) (Official Journal of EU L 331, 14.12.2011).

ECB. Open market operations [online]. c2012, updated on the $28^{\text {th }}$ of September 2012 [cit. 2012-10-15]. Available at: http://www.ecb.int/mopo/implement/omo/html/index.en.html.

ECB. Protocol (No 4) on the Statute of the European System of Central Banks and of the ECB (Official Journal of EU, C 83/230, 30. 3. 2010).

ECB. Target Annual Report 2011 [online]. c2011, updated 2011 [cit. 2012-10-15]. Available at: www.ecb.int/pub/pdf/other/targetar2011en.pdf.

European Commission. (2011) GREEN PAPER on the feasibility of introducing Stability Bonds [online] updated on the $23^{\text {rd }}$ of November 2011 [cit. 2012-10-15]. Available at: eur-lex.europa.eu/LexUriServ/LexUriServ.do?uri=COM:2011:0818:FIN:EN:PDF.

European Commission. (2012a) Communication from the Commission to the European Parliament and Council: A roadmap towards a Banking Union [online] updated on the $12^{\text {th }}$ of September 2012 [cit. 2012-10-15]. Available at:

ec.europa.eu/internal_market/finances/docs/committees/reform/20120912-com2012-510_en.pdf.

European Commission. (2012b) Commission proposes new ECB powers for banking supervision as part of a banking union [online] updated on the $12^{\text {th }}$ of September 2012 [cit. 2012-10-15]. Available at:

europa.eu/rapid/pressReleasesAction.do?reference=IP/12/953\&format=PDF\&aged $=0 \&$ language $=$ EN\&guiLanguage $=$ en .

European Commission. (2012c) Commission proposes package to boost consumer protection and confidence in financial services [online]. c2012, updated on the $12^{\text {th }}$ of September 2012 [cit. 2012-10-15]. Available at:

europa.eu/rapid/pressReleasesAction.do?reference=IP/10/918\&format=PDF\&aged

$=1 \&$ language $=$ EN\&guiLanguage $=$ en .

European Commission. (2012d) New crisis management measures to avoid future bank bail-outs [online]. c2012, updated on the $12^{\text {th }}$ of September 2012 [cit. 2012-10-15]. Available at:

europa.eu/rapid/pressReleasesAction.do?reference=IP/12/570\&format=PDF\&aged $=1$ \&language $=$ EN\&guiLanguage $=$ en.

European Commission. (2012e) Proposal for a Council Regulation conferring specific tasks on the European Central Bank concerning policies relating to the prudential supervision of credit institutions [online]. c2012, updated on the $12^{\text {th }}$ of September 2012 [cit. 2012-10-15]. Available at:

ec.europa.eu/internal_market/finances/docs/committees/reform/20120912-com2012-511_en.pdf. 
European Council. European council 28/29 june 2012 Conclusions [online]. c2012, updated on the $29^{\text {th }}$ of June 2012 [cit. 2012-10-15]. Available at:

www.consilium.europa.eu/uedocs/cms_data/docs/pressdata/en/ec/131388.pdf.

European council. Euro area summit statement [online]. c2012, updated on the $29^{\text {th }}$ of June 2012 [cit. 2012-10-15]. Available at: consilium.europa.eu/uedocs/cms_data/docs/pressdata/en/ec/131359.pdf.

Eurozone portal. 2012. The European Stability Mechanism (ESM) inaugurated [online]. c2012, updated on the $8^{\text {th }}$ of October 2012 [cit. 2012-10-15]. Available at: http://www.eurozone.europa.eu/documents/the-european-stability-mechanism$\% 28$ esm\%29-inaugurated.

Hipp, D. Triumph in Defeat: Euro Ruling Not as Simple as It Seems [online]. c2012, updated on the $13^{\text {th }}$ of September 2012 [cit. 2012-10-15]. Available at: http://www.spiegel.de/international/germany/triumph-in-defeat-ruling-on-esm-ingermany-not-as-simple-as-it-seems-a-855692.html.

Hodson, D., Quaglia, L. European Perspectives on the Global Financial Crisis: Introduction. Journal of Common Market Studies, 2009, vol. 47, no. 5, p. 939-953. ISSN 1468-5965.

Jobst, C., Handig, M., Holzfeind, R. Understanding TARGET 2: The Eurosystem's Euro Payment System from an Economic and Balance Sheet Perspective [online]. c2012 [cit. 2012-10-15]. Available at: www.oenb.at/en/img/mop_2012_q1_tcm16246783.pdf.

Machlica, G., Tóth, P. Zahraničný obchod zlepšil výhliadky slovenskej ekonomiky [online]. c2012, updated on the $15^{\text {th }}$ of June 2012 [cit. 2012-10-15]. Available at: www.finance.gov.sk/Components/CategoryDocuments/s_LoadDocument.aspx?cate goryId $=8228 \&$ documentId $=7326$.

Micossi, S. Bring the Eurozone back from the precipice: An agenda for the European Council [online]. c2012, updated on the $21^{\text {st }}$ of June 2012 [cit. 2012-10-15]. Available at: http://www.voxeu.org/article/bringing-eurozone-back-precipiceproposal.

Milligan, T. Tracking the ELA [online]. c2012, updated on the $6^{\text {th }}$ of September 2012 [cit. 2012-10-15]. Available at: http://www.cumber.com/commentary.aspx?file=090612.asp.

Onaran, Y. Deposit Flight From Europe Banks Eroding Common Currency [online]. c2012, updated on the $19^{\text {th }}$ of September 2012 [cit. 2012-10-15]. Available at: http://www.bloomberg.com/news/2012-09-18/deposit-flight-from-europe-bankseroding-common-currency.html.

Osnabrück University. Euro Crisis Monitor [online]. c2012, updated on the $30^{\text {th }}$ of November 2012 [cit. 2012-10-15]. Available at: http://www.eurocrisismonitor.com/.

Pisani-Ferry, J., Merler, S. Sudden stops in the Eurozone [online]. c2012, updated on the $2^{\text {nd }}$ of April 2012 [cit. 2012-10-15]. Available at:

http://www.voxeu.org/article/public-capital-flows-replacing-private-flowseurozone-what-it-means-policy.

Pisani-Ferry, J., Wolff, G. The Fiscal Implications of a Banking Union [online]. c2012, updated in September 2012 [cit. 2012-10-15]. Available at: 
www.bruegel.org/download/parent/748-the-fiscal-implications-of-a-bankingunion/file/1608-the-fiscal-implications-of-a-banking-union/.

Randow, J. ECB Says Target2 Claims Don't Reflect Central Bank Risk Exposure [online]. c2012, updated on the $31^{\text {st }}$ of May 2012 [cit. 2012-10-15]. Available at: http://www.bloomberg.com/news/2012-05-31/ecb-says-target2-claims-don-t-reflectcentral-bank-risk-exposure.html.

Salmon, F. Don't worry about Target2 [online]. c2012, updated on the $14^{\text {th }}$ of June 2012 [cit. 2012-10-15]. Available at: http://blogs.reuters.com/felixsalmon/2012/06/14/dont-worry-about-target $2 /$.

Saha, D. C., Kessler, M. Blogs review: OMT - Has the ECB solved the Euro Crisis? [online]. c2012, updated on the $25^{\text {th }}$ of September 2012 [cit. 2012-10-15]. Available at: http://www.bruegel.org/nc/blog/detail/article/897-blogs-review-omt-has-the-ecbsolved-the-euro-crisis/.

Shambaugh, J. C. The Euro's Three Crisis [online]. c2012, updated on the $12^{\text {th }}$ of March 2012 [cit. 2012-10-15]. Available at: http://www.brookings.edu/ /media/Files/Programs/ES/BPEA/2012_spring_bpea_pa pers/2012_spring_BPEA_shambaugh.pdf.

Schoenmaker, D., Gros, D. A European Deposit Insurance and Resolution Fund - An Update [online]. c2012, updated on the $11^{\text {th }}$ of September 2012 [cit. 2012-10-15]. Available at: www.ceps.eu/ceps/download/7276.

Sinn, H. W., Wollmershäuser, T. Target Loans, Current Account Balances and Capital Flows: The ECB's Rescue Facility [online]. c2012, updated on the $30^{\text {th }}$ of May 2012 [cit. 2012-10-15]. Available at: www.cesifo-group.de/DocDL/sinn-itax-2012target.pdf.

Storbeck, O. The stealth bailout that doesn't exist: debunking Hans-Werner Sinn [online]. c2011, updated on the $6^{\text {th }}$ of June 2011 [cit. 2012-10-15]. Available at: http://economicsintelligence.com/2011/06/06/the-stealth-bailout-thatdoesn $\%$ E2\%80\%99t-exist-debunking-hans-werner-sinn/.

Van Rompuy, H. Towards a genuine Economic and Monetary Union, Report by President of the European Council Herman Van Rompuy [online]. c2012, updated on the $26^{\text {th }}$ of June 2012 [cit. 2012-10-15]. Available at: www.consilium.europa.eu/uedocs/cms_data/docs/pressdata/en/ec/131201.pdf.

Whelan, K. Target 2: German has bigger things to worry about [online]. c2012, updated on the $29^{\text {th }}$ of April 2012 [cit. 2012-10-15]. Available at: http://www.voxeu.org/article/target2-germany-has-bigger-things-worry-about.

Wolff, G. Arithmetic is absolute: Euroarea Adjustment [online]. c2012, updated in May 2012 [cit. 2012-10-15]. Available at: www.bruegel.org/download/parent/724arithmetic-is-absolute-euro-area-adjustment/file/1581-arithmetic-is-absoluteeuroarea-adjustment/.

Jozef Stískala (1990) is a graduate of the bachelor study programme of the Central European Studies of the Faculty of Public Policies of Silesian University in Opava. Currently, he is a student of the master programme of the 
International Relations and European Studies at Metropolitan University in Prague. His professional interests include both electoral and party systems; in the sphere of European integration, he focuses on the cooperation between the member states of the EU in justice and home affairs. As a Forex trader, he also focuses on the analysis of the European monetary union. E-mail contact: stiskala.j@centrum.sk

Bc. Jozef Stískala Metropolitan University in Prague Dubečská 900/10 10000 Praha 10, Strašnice Česká republika E-mail: stiskala.j@centrum.sk 